\title{
Abbreviated Chronology of Events
}

1963 Kenya gains independence

1969 Kenya People's Union (KPU) banned

1972 ILO report on regional inequalities

1973 GEMA spearheads attempt to "rejuvenate" KANU

1974 General elections

1975 J. M. Kariuki assassinated

1976 Change-the-Constitution Movement sponsored by the "Family"

1977 Abortive KANU party elections

1978 Kenyatta dies in August; Daniel arap Moi becomes president

1979 General elections

1980 Proscription of ethnic welfare societies

1982 Constitutional amendment makes Kenya a de jure singleparty state

1982 Coup attempt in August

1983 Ouster of Minister for Constitutional Affairs Charles Njonjo 
1983 General elections

1985 KANU party elections

1986 Queuing system replaces secret ballot (March)

1986 KANU Disciplinary Committee created

1986 Constitutional Amendment Bill of 1986 eliminates provisions for security of tenure of attorney general, controller, and auditor general

1987 Redistricting creates thirty new constituencies

1987 KANU Disciplinary Committee dissolved; Ministry of National Guidance and Political Affairs created

1988 Constitutional amendment removes security of tenure of judges

1988 KANU party elections called two years early (September)

1990 Kenneth Matiba and Charles Rubia lead call for multiparty system

1990 KANU absorbs confederation of trade unions and the women's movement

1990 Charles Rubia and Kenneth Matiba detained without trial

1990 Saba Saba Day riots (July)

1990 KANU Review Committee formed to assess party procedures

1990 Oginga Odinga hints at creation of new opposition party in November

1991 Student-led protests in Nairobi in mid-November

1991 Donors' meeting in Paris at the end of November leads to suspension of most government-to-government economic assistance, pending improved respect for civil liberties and a clear reduction in levels of corruption; the International Monetary Fund halts loans in December

1991 Moi arrests Nicholas Biwott, former minister of energy, on suspicion that Biwott had personally appropriated foreign aid and participated in the murder of Robert Ouko, the late minister for foreign affairs. On December 3, Moi an- 
nounces that new political parties will be allowed to register

1991 In late December, several cabinet ministers resign to protest the president's failure to call elections within KANU 



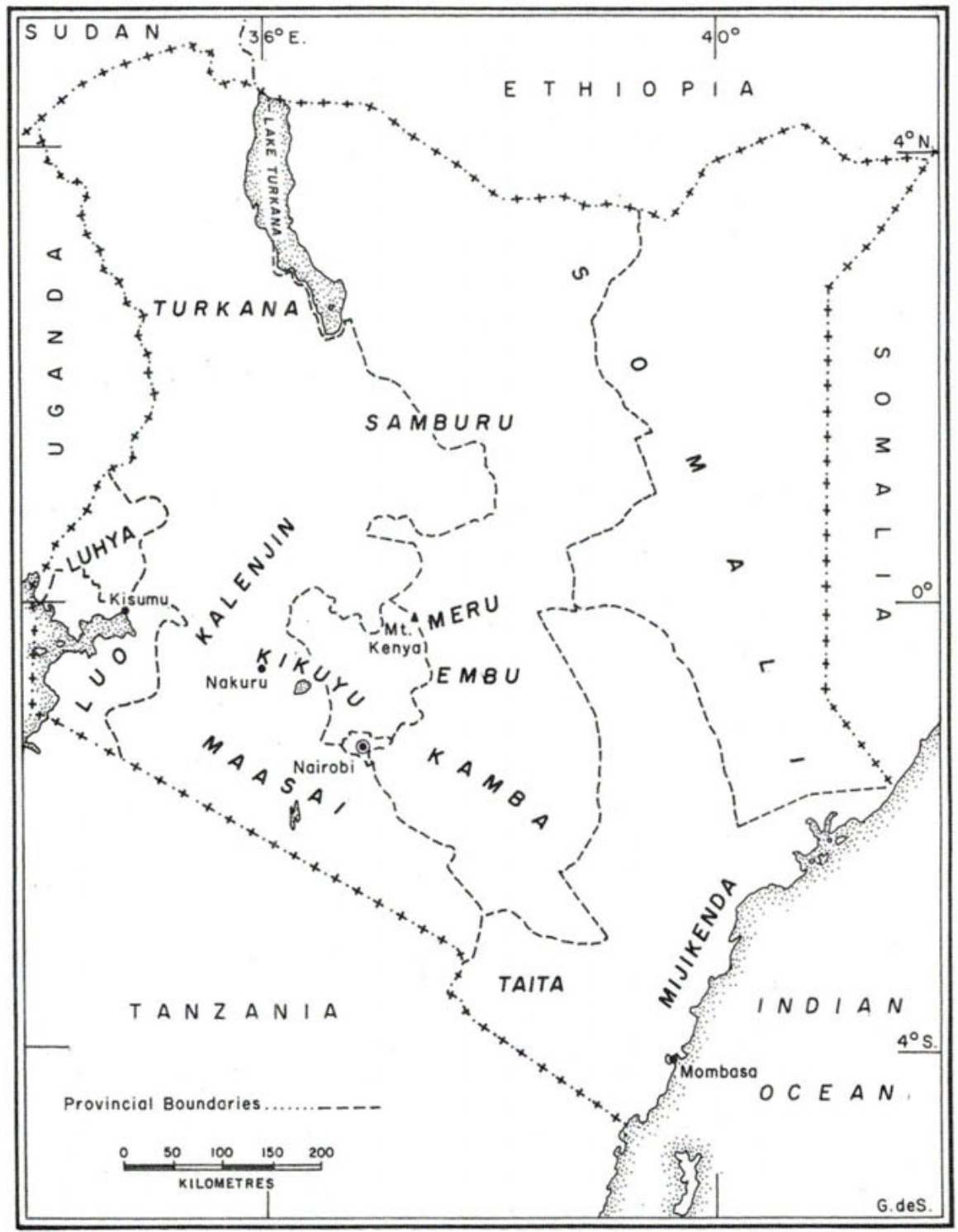

Map 1. Ethno-regional boundaries in Kenya. Source: David Leonard, African Successes: The Public Management of Kenyan Rural Development (Berkeley: University of California Press, 1991), p. xx. 


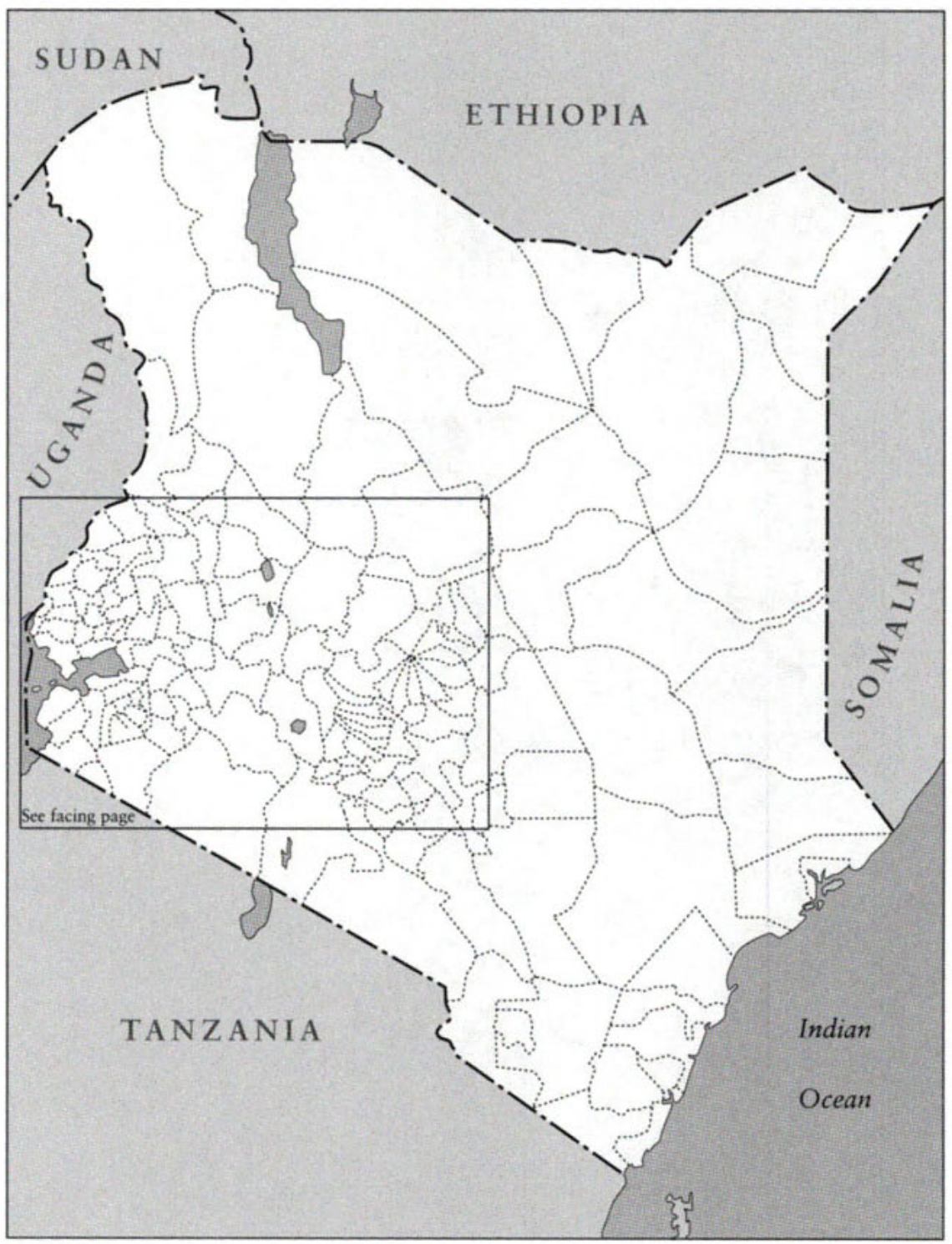

Map 2. Parliamentary constituencies in Kenya, 1963-1987. 


\section{Index to Constituencies Discussed in Text}

$\begin{array}{ll}1 & \text { Embu North } \\ 2 & \text { Embu East } \\ 3 & \text { Embu South } \\ 4 & \text { Kangundo } \\ 5 & \text { Nyandarua South } \\ 6 & \text { Nyandarua North } \\ 7 & \text { Nyeri } \\ 8 & \text { Mathira } \\ 9 & \text { Othaya } \\ 10 & \text { South Tetu (Mukurweini) } \\ 11 & \text { Mbiri } \\ 12 & \text { Kandara } \\ 13 & \text { Makuyu } \\ 14 & \text { Gatundu } \\ 15 & \text { Githunguri }\end{array}$

16 Kiambaa

17 Kikuyu

18 Limuru

19 Eldoret North

20 Eldoret South

21 Tinderet

22 Kericho

23 Lurambi North

24 Lurambi South

25 Mumias

26 Emukhaya

27 Butere

28 Bungoma Central

29 Bungoma South

30 Bungoma East

31 Bondo

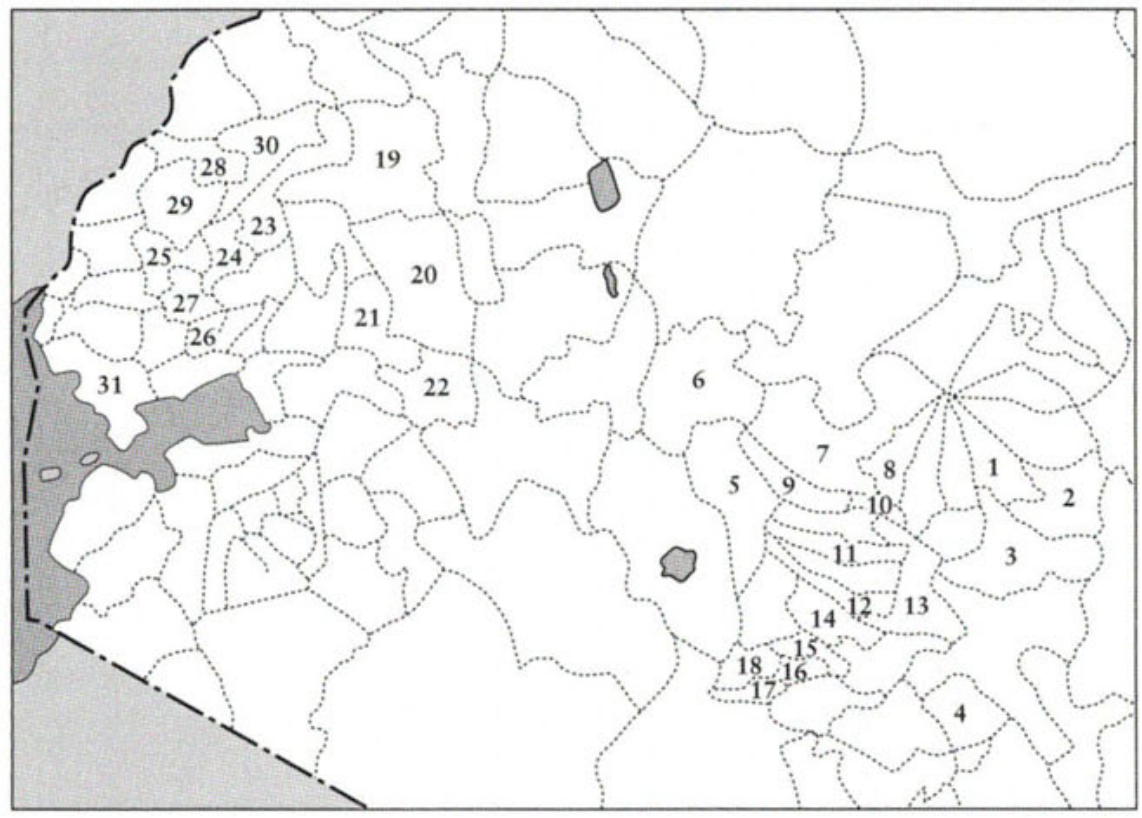


